\title{
Horizonte v. 9, n. 21, abr./jun. 2011
}

\section{Dossiê: Religião e cultura}

\section{Antonio Geraldo Cantarela* \\ Editor}

Antes de apresentar os artigos deste número de Horizonte, gostaríamos de partilhar com os prezados leitores algumas notícias: Nossa revista já tem o número do DOI (Digital Object Identifier). Que significa isso? Trata-se de um sistema de identificação numérico para conteúdo digital, como livros, artigos e documentos disponíveis em redes eletrônicas, como a internet. Serve para autenticar a base administrativa que disponibiliza tais conteúdos. Assim, dentre outras vantagens, um artigo publicado em Horizonte estará relativamente mais protegido de "pirataria intelectual".

Outra informação de interesse: Estamos cadastrados em mais de dez indexadores, alguns internacionais: Espanha (Dialnet), Portugal (ACAAP), Alemanha (UR)... Vale explicar: Se um leitor acessa o portal Livre, do Ministério de Ciência e Tecnologia , encontra lá nossa revista. Já um leitor europeu poderá encontrar a revista pelo indexador UR, portal de periódicos da Universidade de Regensburg, da Alemanha. O fato de estarmos assim "conectados" - para utilizar um jargão do momento - concretiza eficazmente o projeto de disponibilizar nossas pesquisas, reflexões e produções acadêmicas no campo da Teologia e das Ciências da Religião.

As muitas conquistas alcançadas por Horizonte, quer antigas quer recentes, se devem ao trabalho coletivo de professores do Programa de Pós-graduação em Ciências da Religião e da Comissão Editorial. O sucesso de nossa revista se deve também em grande medida à qualidade dos artigos submetidos por nossos autores e pelo valioso trabalho de nossos pareceristas - qualidade garantida pela avaliação ad hoc. Não é por acaso que, de janeiro até o presente momento em que fechamos a edição deste número, Horizonte foi acessada mais de onze mil vezes, dez por cento das quais fora do Brasil.

\footnotetext{
* Doutor em Letras (Literatura) pela PUC Minas (2010). Professor Adjunto da Pontifícia Universidade Católica de Minas Gerais, Departamento de Filosofia e Teologia. País de origem: Brasil. E-mail: agcantarela@yahoo.com..br
}

Horizonte, Belo Horizonte, v. 9, n. 21, p. 196-198, abr./jun. 2011 - ISSN: 2175-584 
Tudo isso, no conjunto, sugere que os artigos publicados por nossa revista estão alcançando grande visibilidade. Mas, diz o velho ditado que "elogio em boca própria é vitupério". Passemos, pois, aos assuntos deste número, dedicado aos entrelaçamentos de Religião e Cultura.

O editorial, assinado por Vinicius Mariano de Carvalho, professor de estudos brasileiros numa universidade da Dinamarca, fala das relações entre religiões, cultura e capitalismo. No contexto omnicapitalista, caracterizado pelo fenômeno da globalização e pelas migrações culturais, também o religioso passa a ser mais um produto de consumo.

Três artigos do dossiê abordam temas relacionados à cultura afrodescendente. Vânia Noronha Alves, em Reinado de Nossa Senhora do Rosário, apresenta o Congado, manifestação católica, típica dos negros, fundada em uma narrativa mítica em torno da Virgem do Rosário. Sérgio Ferretti fala de Comida ritual em festas de Tambor de Mina, religião afro-brasileira do Maranhão e da Amazônia. Em perspectiva que foge ao tema do legado cultural trazido pelo africano, Ana Lúcia Valente caracteriza o papel de resistência desempenhado pelas irmandades de negros, relativamente à instituição do padroado, no período colonial, e à posterior romanização do catolicismo.

Mais particularmente voltados para o contexto católico, encontramos dois artigos. Em As celebrações nas igrejas da ordem terceira de São Francisco, Juliana de Mello Moraes fala das festas entre os seculares franciscanos, no império português do século XVIII. Noutra linha de pesquisa, o artigo de Carolina Teles Lemos tece liames entre o medo da morte e algumas concepções de corpo e de sexualidade, particularmente como são apresentadas pela tradição cristã-católica.

Sem se vincular a uma tradição religiosa em particular, o artigo de Steven Joseph Engler - Constitucional Secularization: Religious Pluralism and the Canadian Courts discute aspectos do direito constitucional canadense a respeito das relações entre Estado e religião. Destaca a compreensão cada vez mais secularizada da religião pelas instâncias judiciais.

Na seção de temática livre, Renato Pfeffer, baseando-se nas reflexões do mestre judeu hassídico Abraham Heschel (1907-1972), defende o protagonismo das religiões para a construção de um novo paradigma de conhecimento em uma sociedade secularizada. Helmuth Renders apresenta o guia medicinal Primitive Physick, de John Wesley, em 
comparação com outras propostas e estratégias terapêuticas em prol da saúde na Inglaterra do século XVIII.

A partir da hermenêutica teológica de Claude Geffré, a comunicação de Elton Vitoriano Ribeiro pergunta pelo estatuto das verdades religiosas.

Não deixem de ler a resenha que Rodrigo Coppe faz do livro La voie du silence dans la tradition des pères du déser (A via do silêncio dentro da tradição dos padres do deserto).

A todos, boa leitura. 